\title{
PENGARUH KUALITAS PRODUK DAN HARGA TERHADAP KEPUASAN KONSUMEN KING TELUR ASIN
}

\author{
Ditia Fitriasshinta \\ Fakultas Manajemen dan Bisnis Universitas Ciputra Surabaya \\ dfitriasshinta@student.ciputra.ac.id \\ Tina Melinda \\ Fakultas Manajemen dan Bisnis Universitas Ciputra Surabaya \\ tina.melinda@ciputra.ac.id
}

\begin{abstract}
ABSTRAK
Olahan makanan dari hasil ternak sudah tidak asing di Indonesia. Selain daging, telur juga dapat diolah menjadi berbagai macam masakan dan makanan. Salah satu di antaranya hasil inovasi pengolahan telur yang sudah ada sekian lama adalah telur asin. Dity Global Nusantara adalah perusahaan yang memproduksi dan menjual telur asin dengan merek dagang KING. Berdiri sejak tahun 2016, perusahaan melakukan penjualan langsung dan bekerjasama melalui reseller. Penelitian ini dilakukan dengan tujuan untuk mengetahui pengaruh kualitas produk dan harga terhadap kepuasan konsumen KING Telur Asin. Penelitian ini menggunakan metode kuantitatif dan model analisis regresi berganda dengan melibatkan konsumen KING Telur Asin sebesar 97 responden kemudian diolah menggunakan SPSS 23. Hasil dari penelitian yang telah dilakukan menyatakan bahwa kualitas produk dan harga memiliki pengaruh positif dan signifikan terhadap kepuasan konsumen KING Telur Asin.
\end{abstract}

Kata kunci:

Kualitas Produk, Harga, Kepuasan Konsumen, Industri Makanan

\begin{abstract}
ABSTRACK
Processed food from livestock products is common in Indonesia. Besides meat, eggs can also be processed into a varyan of dish and food. One of them is the result of egg processed innovation that has been existing for a long time is salted egg. Dity Global Nusantara is a company that produces and sells salted eggs with KING. It has been established since 2016, the company sells directly and cooperates through reseller. This research is doe in the purpose of finding out the influence of product quality and price on consumer satisfaction of KING Salted Egg. This research uses quantitative method and multiple regression analysis model by involving KING Salted Egg consumer of 97 respondents as a sample then processedd by using 23 SPSS. The result of this research that has been done states that product quality and price have positivee influence and significant on consumer satisfaction of KING Salted Egg.
\end{abstract}

Keywords:

Product Quality, Price, Customer Satisfaction, Food Industry 


\section{PENDAHULUAN}

Telur asin merupakan salah satu sumber protein yang mudah didapat dan berharga relatif terjangkau. Perkembangan industri telur asin akan mendorong perkembangan peternakan itik yang berdampak pada peningkatan pendapatan para peternak itik yang umumnya merupakan masyarakat pedesaan. Pusat produksi telur asin umumnya berlokasi sama dengan sentra penghasil telur asin. Direktorat Jenderal Peternakan menyebutkan produksi telur konsumsi nasional urutan pertama ditempati oleh telur ayam ras kemudian nomor dua telur itik dan berlanjut pada telur ayam kampung, itik manila dan puyuh.

Dity Global Nusantara adalah salah satu perusahaan yang bergerak di industri olahan hasil ternak khususnya telur itik yang diolah menjadi telur asin. Perusahaan memiliki merek dagang "KING" untuk produk telur asinnya. KING Telur Asin tidak menggunakan zat kimia pada proses produksi sehingga masa simpan telur hanya 7 hari. Oleh karena itu, persoalan terkait masa simpan menjadi pertimbangan calon konsumen sebelum membeli.
Tabel 1.

Daftar Keluhan Konsumen

\begin{tabular}{|r|l|c|c|}
\hline No. & \multicolumn{1}{|c|}{ Keluhan } & Frekuensi & Presentase \\
\hline 1. & $\begin{array}{l}\text { Masa simpan } \\
\text { tidak lama }\end{array}$ & 6 & $30 \%$ \\
\hline 2. & $\begin{array}{l}\text { Warna kuning } \\
\text { telur berbeda- } \\
\text { beda }\end{array}$ & 8 & $40 \%$ \\
\hline 3. & $\begin{array}{l}\text { Harga jual yang } \\
\text { berubah-ubah }\end{array}$ & 4 & $20 \%$ \\
\hline 4. & $\begin{array}{l}\text { Ukuran fisik } \\
\text { yang lebih kecil }\end{array}$ & 2 & $10 \%$ \\
\hline & Jumlah & $100 \%$ \\
\hline
\end{tabular}

Sumber: Data Primer 2018 (diolah)

Daftar keluhan konsumen dapat dilihat pada Tabel 1 terkait dasar penilaian kualitas produk yang mempengaruhi kepuasan konsumen.

Harga jual dari King Telur Asin terbilang lebih rendah dibanding kompetitor namun hal itu tidak menjamin konsumen memperoleh kepuasan hingga tidak beralih pada produk kompetitor yang memiliki harga lebih tinggi.

Pada Gambar 1, dapat dilihat pertumbuhan penjualan dari produk telur asin King selama Triwulan 1 sampai dengan Triwulan 4. Bila dilihat dari omzet penjualan maka terjadi kenaikan penjualan dari Triwulan 2 sampai ke Triwulan 4. Kenaikan penjualan tersebut terjadi saat perusahaan melakukan penjualan langsung di toko retail. 
Pengaruh Kualitas Produk dan Harga terhadap...(Ditia Fitriasshinta \& Tina Melinda)

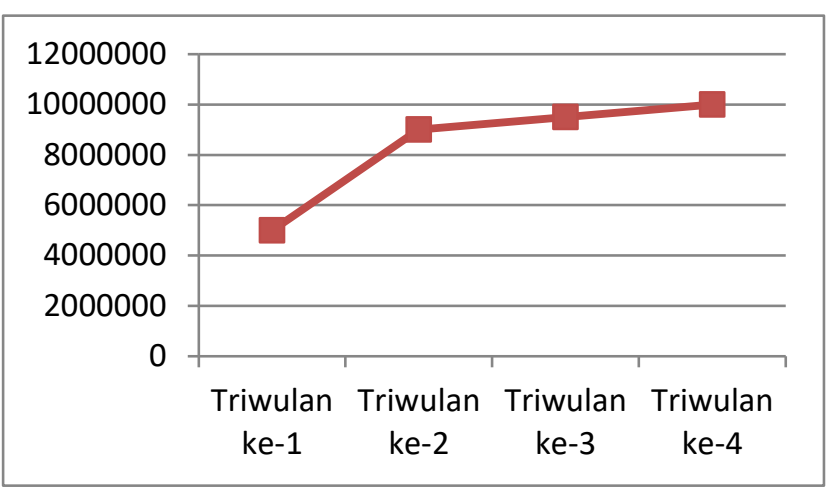

Gambar 1 Grafik Omset Perusahaan

Tahun 2017

Sumber: Data internal (2017)

Menurut Samsul Ramli (2013), harga disebutkan sebagai nilai relatif dari produk dan bukan indikator pasti dalam menunjukkan besarnya sumber daya yang diperlukan dalam menghasilkan produk, hal ini menyatakan bahwa penetapan harga suatu produk dapat bervariasi dan bergantung pada penetapan dari produsen.

Menurut Feingenbaum dalam Marwanto (2015), kualitas produk merupakan salah satu gabungan karakteristik produk dari pemasaran, rekayasa (perencanaan), pembuatan (produk) dan pemeliharaan yang membuat produk yang digunakan memenuhi harapan-harapan pelanggan.

Menurut Kotler (2014), kepuasan pelanggan didefinisikan sebagai perasaan senang atau kecewa yang muncul setelah membandingkan kinerja (hasil) produk yang dipikirkan terhadap kinerja (atau hasil) yang diharapkan.

Berdasarkan hasil kajian sebelumnya, tujuan penelitian ini adalah untuk mengetahui apakah kualitas produk memiliki pengaruh terhadap kepuasan konsumen dan mengetahui apakah harga juga berpengaruh terhadap kepuasan konsumen.

\section{TINJAUAN TEORI DAN \\ PENGEMBANGAN HIPOTESIS}

\section{Kepuasan Konsumen}

Menurut Rangkuti (2013), kepuasan konsumen adalah evaluasi pasca pembelian, dimana alternatif yang dibeli minimal sama atau melebihi harapan pelanggan. Berdasarkan pengertian ini, maka kepuasan konsumen adalah tingkat perasaan seseorang setelah membandingkan kinerja atau hasil yang ia rasakan dibanding dengan harapannya.

Sedangkan menurut Kotler (2014), kepuasan pelanggan didefinisikan sebagai perasaan senang atau kecewa yang muncul setelah membandingkan kinerja (hasil) produk yang dipikirkan terhadap kinerja (atau hasil) yang diharapkan. Indikator kepuasan konsumen dapat dilihat dari: (1) Re-purchase. Membeli kembali, dimana pelanggan tersebut akan kembali kepada perusahaan untuk membeli 
barang/jasa; (2) Menciptakan word of mouth.

Pelanggan akan mengatakan hal-hal yang baik tentang perusahaan kepada orang lain; (3) Menciptakan citra merek. Pelanggan akan kurang memperhatikan merek dan iklan dari produk pesaing; (4) Menciptakan keputusan pembelian pada perusahaan yang sama. Membeli kembali produk lain dari perusahaan yang sama.

\section{Kualitas Produk}

Kulitas produk merupakan seluruh gabungan karakteristik produk dari pemasaran, rekayasa (perencanaan), pembuatan (produk) dan pemeliharaan yang membuat produk yang digunakan memenuhi harapan pelanggan menurut Feingenbaum dalam Marwanto (2015). Menurut Garvin (2013), terdapat 8 dimensi ukuran pandangan konsumen terhadap kualitas produk, yaitu: (1) Dimensi Kinerja Produk (Performance). Kinerja merupakan karakteristik atau fungsi utama suatu produk. Hal ini merupakan manfaat atau khasiat utama produk yang dibeli. Biasanya manfaat atau khasiat utama produk menjadi pertimbangan pertama dalam membeli; (2) Dimensi Keandalan Produk (Reliability). Keterandalan yang dimaksudkan adalah peluang suatu produk untuk bebas dari kegagalan saat menjalankan fungsifungsinya; (3) Dimensi Fitur Produk (Feature).
Dimensi fitur merupakan karakteristik atau ciriciri tambahan yang melengkapi manfaat dasar suatu produk. Fitur bersifat pilihan bagi konsumen. Jika manfaat utama sudah memiliki standar kualitas maka penambahan fitur seringkali ditambahkan. Idealnya, fitur dapat meningkatkan kualitas produk di antara para pesaing; (4) Dimensi Daya Tahan (Durability). Daya tahan menunjukkan usia produk, yaitu jumlah pemakaian suatu produk sebelum produk tersebut digantikan atau rusak. Semakin lama daya tahan suatu produk, akan dipersepsikan lebih berkualitas dibanding produk yang cepat habis masa simpannya; (5) Dimensi Kesesuaian (Conformance). Dimensi kesesuaian adalah kesesuaian kinerja produk dengan standar yang dinyatakan oleh suatu produk. Semacam ketepatan untuk memenuhi standar yang telah ditentukan. Produk yang memiliki kualitas dengan dimensi kesesuaian dapat diartikan memiliki kesesuaian dengan standarnya; (6) Dimensi Kemampuan Diperbaiki (Service Ability). Sesuai dengan maknanya, disini kualitas produk ditentukan atas dasar kemampuan diperbaiki, mudah, cepat, dan kompeten. Produk yang mampu diperbaiki memiliki kualitas lebih tinggi dibandingkan produk yang tidak atau sulit diperbaiki; (7) Dimensi Keindahan Tampilan Produk (Aesthetic). 
Aesthetic atau keindahan menyangkut tampilan produk yang membuat konsumen menyukainya. Seringkali dilakukan dalam bentuk desain produk kemasannya. Beberapa merek memperbarui tampilannya supaya lebih cantik di mata konsumen; (8) Dimensi Kualitas yang Dirasakan (Preceived Quality). Dimensi terakhir adalah kualitas yang dirasakan. Hal ini menyangkut penilaian konsumen terhadap citra, merek, atau iklan suatu produk. Produk-produk yang bermerek terkenal biasanya dipersepsikan lebih berkualitas dibandingkan merek-merek yang tidak terkenal. Itulah sebabnya produk selalu berupaya membangun mereknya sehingga memiliki brand equity yang tinggi.

\section{Harga}

Menurut Danang Sunyoto (2013) harga itu sebenarnya merupakan nilai yang dinyatakan dalam suatu mata uang atau alat tukar, terhadap suatu produk tertentu. Dalam kenyataannya, besar kecilnya nilai atau harga itu tidak hanya ditentukan oleh faktor fisik saja yang diperhitungkan tetapi faktor-faktor psikologis dan faktor-faktor lain berpengaruh pula terhadap harga. Jadi pengertian harga adalah sejumlah uang yang dibutuhkan untuk mendapatkan sejumlah produk tertentu atau kombinasi antara barang dan jasa. Beda halnya menurut Setyaningrum (2015). Menurutnya, harga adalah satu-satunya unsur dalam kegiatan pemasaran yang menghasilkan pendapatan penjualan. Terdapat beberapa indikator yang mencirikan harga menurut Kotler dalam Rezki (2014), di antaranya sebagai berikut: (1) Keterjangkauan harga; (2) Kesesuaian harga dengan kualitas produk; (3) Daya saing harga; (4) Kesesuaian harga dengan manfaat produksi; (5) Harga mempengaruhi daya beli konsumen; (6) Harga dapat mempengaruhi konsumen dalam mengambil keputusan.

Selain itu Kotler dan Armstrong (2013) juga berpendapat bahwa harga adalah sejumlah uang yang dibebankan atas suatu barang atau jasa atau jumlah dari nilai uang yang ditukar konsumen atas manfaat-manfaat karena memiliki atau menggunakan produk atau jasa tersebut.

\section{METODE RISET}

Penelitian ini menggunakan pendekatan kuantitatif dengan tipe eksplanasi untuk menjelaskan hubungan sebab akibat antara varibel (Sunyoto (2009). Populasi dari penelitian ini menggunakan seluruh konsumen yang membeli produk KING Telur Asin, dan karena keterbatasan dana, tenaga dan waktu 
maka penelitian dapat menggunakan sampel yang diambil dari populasi (Sugiyono, 2015:73). Populasi dalam penelitian ini tidak diketahui jumlahnya sehingga untuk menghitung jumlah sampel minimum yang dibutuhkan menggunakan formula Lemeshow untuk populasi yang tidak diketahui. Berdasarkan rumus tersebut, sampel yang didapatkan adalah sebesar 96,04 sehingga pada penelitian ini setidaknya mengambil data dari sampel sekurang-kurangnya sejumlah 97 orang. Pada penelitian ini memiliki dua sumber data yang terdiri dari data primer dan data sekunder. Data primer diperoleh dari kuesioner yang diberikan kepada 97 orang yang menjadi responden penelitian sedangkan data sekunder diperoleh dari referensi buku dan jurnal sebagai acuan. Pengumpulan untuk data primer, peneliti menggunakan kuesioner dengan beberapa alternatif jawaban berupa skala Likert.

Penelitian ini memiliki 3 variabel yaitu kualitas produk $\left(X_{1}\right)$ dan harga $\left(X_{2}\right)$ sebagai variabel bebas dan kepuasan konsumen (Y) sebagai variabel terikat. Berikut ini adalah pemaparan mengenai definisi operasional variabel penelitian.
Kualitas produk menurut Feingenbaum dalam Marwanto (2015) merupakan seluruh gabungan karakteristik produk dari pemasaran, rekayasa (perencanaan), pembuatan (produk) dan pemeliharaan yang membuat produk yang digunakan memenuhi harapan pelanggan. Indikator dari kualitas produk menggunakan pendapat Garvin (2013) yang menyatakan bahwa terdapat 5 dimensi ukuran pandangan konsumen terhadap kualitas produk, yaitu: (1) Performance; (2) Durability; (3) Aesthetic; (4) Conformance; (5) Perceived quality (kualitas yang dirasakan).

$$
\text { Harga menurut Setyaningrum }
$$
(2015:128) adalah satu-satunya unsur dalam kegiatan pemasaran yang menghasilkan pendapatan penjualan, indikator harga yang digunakan dalam penelitian ini (Rezki, 2014:5), adalah: (1) Keterjangkauan harga; (2) Kesesuaian harga dengan kualitas produk; (3) Daya saing harga; (4) Kesesuaian harga dengan manfaat produksi; dan (5) Harga mempengaruhi daya beli konsumen. 
Kepuasan Konsumen menurut Rangkuti (2013) adalah evaluasi pasca pembelian, dimana alternatif yang dibeli minimal sama atau melebihi harapan pelanggan. Indikator yang dapat mempengaruhi kepuasan konsumen (Kotler, 2014) yaitu: (1) Repurchase; (2) Menciptakan word of mouth; dan (3) Menciptakan citra merek.

\section{HASIL PENELITIAN}

DAN

\section{PEMBAHASAN}

\section{Deskripsi Hasil Penelitian}

Berdasarkan kuesioner yang telah disebarkan kepada responden, maka data responden berdasarkan jenis kelamin menghasilkan 63 orang berjenis kelamin perempuan atau sebesar $65 \%$ dan sisanya sebesar 35\% dengan jumlah 34 orang berjenis kelamin laki-laki. Ditinjau berdasarkan usia menunjukkan bahwa responden berusia lebih dari 35 tahun dengan jumlah terbanyak sebesar 77 orang $(79,4 \%)$ diikuti usia $18-24$ tahun sebanyak 14 orang $(14,5 \%)$ berlanjut pada usia 25-34 tahun dengan jumlah 4 orang $(4,1 \%)$ dan terakhir usia 12-17 tahun sebanyak 2 orang (2\%). Ditinjau dari frekuensi pembelian dari total 97 responden sebanyak 18 orang (18\%) telah melakukan pembelian sebanyak 2 kali,
34 orang $(35 \%)$ sebanyak 3 kali, 23 orang (24\%) sebanyak 4 kali dan 22 orang (23\%) sebanyak lebih dari 4 kali. Mean dari variabel kualitas produk dan harga sebanyak 3,582 dan 3,636 yang artinya rata-rata responden setuju dengan pernyataan pada responden. Mean dari variabel kepuasan konsumen juga menunjukkan rata-rata responden setuju dengan nilai mean sebanyak 3,625.

\section{Validitas dan Reliabilitas}

Tabel 2 menunjukkan hasil pengujian validitas dan reliabilitas pada masing-masing variabel penelitian menggunakan correlation pearson dan cronbarch's alpha.

Berdasarkan Tabel 2, dapat dilihat bahwa semua pernyataan variabel memiliki tingkat signifikansi $<0,05$ sehingga dapat disimpulkan bahwa semua jawaban pernyataan valid.

Tabel 3 menunjukkan keseluruhan variabel yang digunakan dalam penelitian ini memiliki nilai Cronbach's Alpha lebih dari 0,06. Oleh karena itu dapat disimpulkan kuesioner yang digunakan dalam penelitian ini reliabel. 
Tabel 2.

Hasil Uji Validitas

\begin{tabular}{|c|c|c|c|c|}
\hline \multirow{4}{*}{$\begin{array}{c}\text { Variab } \\
\text { el }\end{array}$} & $\begin{array}{c}\text { Indikat } \\
\text { or }\end{array}$ & $\begin{array}{c}\text { Correlati } \\
\text { on } \\
\text { pearson }\end{array}$ & Sig. & $\begin{array}{c}\text { Kesimpu } \\
\text { lan }\end{array}$ \\
\hline \multirow{4}{*}{$X_{1}$} & $X_{1.1}$ & 0,800 & $\begin{array}{c}0,00 \\
0\end{array}$ & Valid \\
\cline { 2 - 5 } & $X_{1.2}$ & 0,768 & $\begin{array}{c}0,00 \\
0\end{array}$ & Valid \\
\cline { 2 - 5 } & $X_{1.3}$ & 0,825 & $\begin{array}{c}0,00 \\
0\end{array}$ & Valid \\
\cline { 2 - 5 } & $X_{1.4}$ & 0,213 & $\begin{array}{c}0,03 \\
6\end{array}$ & Valid \\
\cline { 2 - 5 } & $X_{1.5}$ & 0,794 & $\begin{array}{c}0,00 \\
0\end{array}$ & Valid \\
\hline \multirow{7}{*}{$X_{2}$} & $X_{2.1}$ & 0,683 & $\begin{array}{c}0,00 \\
0\end{array}$ & Valid \\
\cline { 2 - 5 } & $X_{2.2}$ & 0,626 & $\begin{array}{c}0,00 \\
0\end{array}$ & Valid \\
\cline { 2 - 5 } & $X_{2.3}$ & 0,729 & $\begin{array}{c}0,00 \\
0\end{array}$ & Valid \\
\cline { 2 - 5 } & $X_{2.4}$ & 0,538 & $\begin{array}{c}0,00 \\
0\end{array}$ & Valid \\
\cline { 2 - 5 } & $X_{2.5}$ & 0,510 & $\begin{array}{c}0,00 \\
0\end{array}$ & Valid \\
\cline { 2 - 5 } & $X_{2.6}$ & 0,649 & $\begin{array}{c}0,00 \\
0\end{array}$ & Valid \\
\hline \multirow{7}{*}{$Y$} & $Y_{1.1}$ & 0,774 & $\begin{array}{c}0,00 \\
0\end{array}$ & Valid \\
\cline { 2 - 5 } & $Y_{1.2}$ & 0,656 & $\begin{array}{c}0,00 \\
0\end{array}$ & Valid \\
\cline { 2 - 5 } & $Y_{1.3}$ & 0,638 & $\begin{array}{c}0,00 \\
0\end{array}$ & Valid \\
\cline { 2 - 5 } & $Y_{1.4}$ & 0,676 & $\begin{array}{c}0,00 \\
0\end{array}$ & Valid \\
\hline
\end{tabular}

Sumber: Data diolah (2018)

Tabel 3

Hasil Uji Reliabilitas

\begin{tabular}{|l|c|c|}
\hline \multicolumn{1}{|c|}{ Variabel } & $\begin{array}{c}\text { Cronbach's } \\
\text { Alpha }\end{array}$ & Keterangan \\
\hline $\begin{array}{l}\text { Kualitas Produk } \\
\left(X_{1}\right)\end{array}$ & 0,708 & Reliabel \\
\hline Harga $\left(X_{2}\right)$ & 0,687 & Reliabel \\
\hline $\begin{array}{l}\text { Kepuasan } \\
\text { Konsumen }(Y)\end{array}$ & 0,623 & Reliabel \\
\hline
\end{tabular}

Sumber: Data diolah (2018)

\section{Analisis Regresi Linear Berganda}

Tabel 4 menunjukkan hasil analisis regresi pada penelitian ini.
Tabel 4.

Regresi Linear Berganda

\begin{tabular}{|c|l|r|r|r|r|}
\hline \multirow{2}{*}{\multicolumn{2}{|c|}{ Model }} & \multicolumn{2}{|c|}{$\begin{array}{c}\text { Unstandardize } \\
\text { d Coefficients }\end{array}$} & \multirow{2}{*}{ T } & \multirow{2}{*}{ Sig. } \\
\cline { 3 - 6 } \multicolumn{2}{|c|}{} & B & $\begin{array}{r}\text { Std. } \\
\text { Error }\end{array}$ & & \\
\hline 1 & (Constant) &, 820 & 1,289 &, 636 &, 526 \\
\hline & X1 &, 288 &, 075 & 3,820 &, 000 \\
\cline { 2 - 6 } & X2 &, 382 &, 072 & 5,324 &, 000 \\
\hline
\end{tabular}

Sumber: Data diolah (2018)

Berdasarkan pada Tabel 4, dapat dinyatakan bahwa persamaan regresi linear berganda pada penelitian ini sebagai berikut:

$$
\mathrm{Y}=0,820+0,288 X_{1}+0,382 X_{2}
$$

Berdasarkan persamaan regresi liniear di atas, maka dapat disimpulkan bahwa kualitas produk dan harga berpengaruh signifikan dan positif terhadap kepuasan konsumen, dan dapat dijelaskan jika warna telur semakin kuat dan tidak beraroma amis (indikator kualitas produk), maka dapat meningkatkan kepuasan konsumen sebesar 0,288 dan jika harga semakin sesuai kualitas produk serta manfaat produksi (indikator harga), maka dapat meningkatkan kepuasan konsumen sebesar 0,382.

\section{Uji F}

Pada tabel 5, tertera hasil uji $\mathrm{F}$ dalam penelitian ini. 
Tabel 5.

Hasil Uji F

\begin{tabular}{|l|l|l|l|l|l|}
\hline \multicolumn{2}{|l|}{ Model } & df & $\begin{array}{l}\text { Mean } \\
\text { Square }\end{array}$ & F & Sig. \\
\hline \multirow{4}{*}{1} & Regression & 2 & 179,648 & $\begin{array}{l}56,0 \\
96\end{array}$ & $\begin{array}{l}000 \\
\text { b }\end{array}$ \\
\cline { 2 - 6 } & Residual & 94 & 3,202 & & \\
\cline { 2 - 6 } & Total & 96 & & & \\
\hline
\end{tabular}

Sumber: Data diolah (2018)

Berdasarkan Tabel 5, maka dapat dijelaskan bahwa nilai $F$ hitung yang didapatkan sebesar 56,096 dengan tingkat signifikansi 0,000 yang berarti lebih kecil dari 0,05. Hal ini menunjukkan bahwa kualitas produk dan harga memiliki pengaruh terhadap kepuasan konsumen. Model regresi untuk penelitian ini dapat digunakan karena telah lulus dalam uji goodness fit of model di mana tidak ada perbedaan antara data sehingga model regresi dapat dikatakan fit untuk penelitian ini (Ghozali, 2016)

\section{Uji t}

Berdasarkan Tabel 6 hasil pengujian hipotesis dengan menggunakan Uji t adalah sebagai berikut:
Tabel 6.

Hasil Uji t

\begin{tabular}{|l|l|l|l|}
\hline \multicolumn{2}{|l|}{ Model } & $\mathrm{t}$ & Sig. \\
\hline 1 & $($ Constant $)$ &, 636 &, 526 \\
\cline { 2 - 4 } & Kualitas Produk $\left(X_{1}\right)$ & 3,82 &, 000 \\
& & 0 & \\
\cline { 2 - 4 } & Harga $\left(X_{2}\right)$ & 5,32 &, 000 \\
& & 4 & \\
\hline
\end{tabular}

Sumber: Data diolah (2018)

1. Kualitas Produk $\left(X_{1}\right)$ memiliki nilai $\mathrm{t}$ hitung sebesar 3,820 dengan tingkat signifikansi 0,000 yang kurang dari 0,05 sehingga dapat dinyatakan kualitas produk berpengaruh signifikan terhadap kepuasan konsumen KING Telur Asin serta dan dapat disimpulkan bahwa hipotesis $H_{1}$ diterima.

2. Harga $\left(X_{2}\right)$ memiliki nilai t hitung sebesar 5,324 dengan tingkat signifikansi 0,000 yang kurang dari 0,05 sehingga dapat dinyatakan harga berpengaruh signifikan terhadap kepuasan konsumen KING Telur Asin dan dapat disimpulkan hipotesis $H_{1}$ diterima. 
Koefisien Korelasi (R) dan Koefisien Determinasi $\left(R^{2}\right)$

Tabel 7.

Koefisien Korelasi ( $R$ ) dan Koefisien Determinasi $\left(R^{2}\right)$

\begin{tabular}{|c|c|c|c|}
\hline Model & $\begin{array}{c}\text { Koefisien } \\
\text { Korelasi } \\
(\mathrm{R})\end{array}$ & $\begin{array}{c}\text { Koefisien } \\
\text { Determinasi } \\
\left(R^{2}\right)\end{array}$ & $\begin{array}{c}\text { Adjusted } \\
\text { R Square }\end{array}$ \\
\hline 1 & 0,738 & 0,544 & 0,534 \\
\hline
\end{tabular}

Sumber: Data diolah (2018)

Pada Tabel 7 diketahui nilai koefisien korelasi (R) sebesar 0,738 yang artinya terdapat hubungan kuat antara variabel bebas yang terdiri dari Kualitas Produk $\left(X_{1}\right)$ dan Harga $\left(X_{2}\right)$ dengan variabel terikat yaitu Kepuasan Konsumen (Y). Sedangkan untuk koefisien determinasi $\left(R^{2}\right)$ sebesar 0,544 yang menjelaskan bahwa kemampuan model menerangkan Kepuasan Konsumen (Y) adalah sebesar $\quad 54,4 \%$ sementara $45,6 \%$ (yang didapatkan berdasarkan hitungan 100\%$54,4 \%$ ) dipengaruhi oleh faktor lain yang tidak serta diteliti dalam penelitian ini.

\section{Uji Asumsi Klasik}

\section{Uji Normalitas}

Pada Tabel 8 menunjukkan bahwa hasil signifikansi dalam uji kolmogorov smirnov sebesar 0,160 yang lebih besar dari 0,05 (syarat signifikansi) sehingga dapat disimpulkan residual model regresi berdistribusi normal dan menegaskan model
Tabel 8.

Hasil Uji Normalitas

\begin{tabular}{|c|c|c|}
\hline \multicolumn{3}{|c|}{ Unstandardized Residual } \\
\hline $\begin{array}{c}\text { Kolmogorov- } \\
\text { Smirnov Z }\end{array}$ & $\mathrm{N}$ & $\begin{array}{c}\text { Asymp.Sig. (2- } \\
\text { tailed) }\end{array}$ \\
\hline 1,123 & 97 & 0,160 \\
\hline
\end{tabular}

Sumber: Data diolah (2018)

Tabel 9.

Hasil Uji Multikolinearitas

\begin{tabular}{|l|c|c|c|}
\hline $\begin{array}{c}\text { Variabel } \\
\text { Bebas }\end{array}$ & Tollerance & VIF & Keterangan \\
\hline $\begin{array}{l}\text { Kualitas } \\
\text { Produk ( } \\
\left.X_{1}\right)\end{array}$ & 0,609 & 1,64 & $\begin{array}{c}\text { Tidak terjadi } \\
\text { multikolinearita } \\
\text { s }\end{array}$ \\
\hline $\begin{array}{l}\text { Harga ( } \\
\left.X_{2}\right)\end{array}$ & 0,609 & 1,64 & $\begin{array}{c}\text { Tidak terjadi } \\
\text { multikolinearita } \\
\text { s }\end{array}$ \\
\hline
\end{tabular}

Sumber: Data diolah (2018)

regresi yang dihasilkan dapat digunakan untuk mengambil kesimpulan.

\section{Uji Multikolinearitas}

Berdasarkan Tabel 9 dapat disimpulkan tidak terjadi multikolinearitas karena nilai VIF dari variabel Kualitas Produk dan Harga $<10$.

\section{Uji Heterokedasititas}

Berdasarkan Tabel 10 nilai signifikansi Kualitas Produk $\left(X_{1}\right)$ dan Harga $\left(X_{2}\right)$ lebih besar dari 0,05 sehingga tidak terjadi gejala heterokedasititas dalam model regresi penelitan ini. 
Tabel 10.

Hasil Uji Heterokedasititas

\begin{tabular}{|c|l|r|r|r|}
\hline \multicolumn{2}{|c|}{} & \multicolumn{2}{|c|}{$\begin{array}{c}\text { Unstandardized } \\
\text { Coefficients }\end{array}$} & \multirow{2}{*}{ Sig. } \\
\cline { 3 - 4 } \multicolumn{2}{|c|}{ Model } & B & $\begin{array}{c}\text { Std. } \\
\text { Error }\end{array}$ & \multicolumn{1}{|c|}{} \\
\hline \multirow{2}{*}{1} & (Constant) & 1,111 &, 891 &, 216 \\
\cline { 2 - 4 } & X1 &, 005 &, 052 &, 927 \\
\cline { 2 - 4 } & X2 &, 003 &, 050 &, 944 \\
\hline
\end{tabular}

Sumber: Data diolah (2018)

Tabel 11.

Hasil Uji Autokorelasi

\begin{tabular}{|c|c|c|c|c|}
\hline $\mathrm{D}$ & DL & DU & 4-DL & 4-DU \\
\hline 2,15 & 1,6275 & 1,7115 & 2,3724 & 2,2884 \\
7 & 2 & 7 & 8 & 3 \\
\hline
\end{tabular}

Sumber: Data diolah (2018)

\section{Uji Autokorelasi}

Tabel 11 menyatakan bahwa nilai Durbin-Watson yang dihasilkan adalah sebesar 2,157. Nilai tersebut lebih besar dari DU $(1,71157)$ dan lebih kecil dari 4-DU $(2,28843)$ maka $H_{o}$ diterima yang artinya tidak terjadi autokorelasi.

\section{Uji Linearitas}

Tabel 12 menjelaskan bahwa nilai sig. Deviation from Linearity pada masing-masing variabel kualitas produk dan harga sebesar 0,303 dan 0,949 yang lebih besar dari 0,05 . Hal tersebut dapat disimpulkan terdapat hubungan yang linier antara kualitas produk dan harga terhadap kepuasan konsumen.
Tabel 12.

Hasil Uji Linearitas

\begin{tabular}{|c|c|c|c|}
\hline $\begin{array}{c}\text { Variabe } \\
\text { 1 Bebas }\end{array}$ & $\begin{array}{c}\text { Variabel } \\
\text { Terikat }\end{array}$ & $\begin{array}{c}\text { Sig. } \\
\text { Deviatio } \\
\text { n from } \\
\text { Linearity }\end{array}$ & $\begin{array}{c}\text { Keteranga } \\
\mathrm{n}\end{array}$ \\
\hline $\begin{array}{c}\text { Kualitas } \\
\text { Produk } \\
\left(X_{1}\right)\end{array}$ & $\begin{array}{c}\text { Keputusa } \\
\mathrm{n}\end{array}$ & 0,303 & Linear \\
\cline { 1 - 1 } $\begin{array}{c}\text { Pembelian } \\
\left(X_{2}\right)\end{array}$ & $(\mathrm{Y})$ & 0,949 & Linear \\
& & & \\
\hline
\end{tabular}

Sumber: Data diolah (2018)

\section{PEMBAHASAN}

\section{Pengaruh Kualitas Produk Terhadap}

\section{Kepuasan Konsumen}

Kualitas produk dinyatakan berpengaruh signifikan terhadap kepuasan konsumen dengan pertimbangan dari uji t yang menghasilkan nilai $\mathrm{t}$ hitung sebesar 3,820 dengan tingkat signifikansi 0,000 yang kurang dari 0,05 sehingga dapat dinyatakan kualitas produk berpengaruh signifikan terhadap kepuasan konsumen KING Telur Asin. Produk KING Telur Asin memang memiliki perbedaan dari segi tampilan telur dibanding para kompetitor di Surabaya, berukuran lebih mini namun terlihat bersih, hal itu yang menjadi faktor para responden menilai KING telur asin memiliki tampilan yang menarik. Selain itu, perusahaan memang memperjelas perbedaan tampilan telur dengan pemberian nametag pada tempat penjualan. Warna kuning telur asin perusahaan memang tidak berwarna 
pekat dan tidak seragam antar produk maka jawaban paling bervariasi terdapat pada indikator kualitas telur yang baik (warna kuning menarik, tidak berbau amis, dan bersih). Indiakator lain yang cukup disetujui oleh responden terkait kualitas produk adalah masa simpan produk. Perusahaan memiliki masa simpan kurang dari 7 hari dan jawaban tersebut menghasilkan jawaban paling homogen dibanding pernyataan lainnya. Hasil penelitian menyimpulkan bahwa kualitas produk berpengaruh signifikan terhadap kepuasan konsumen KING Telur Asin. Hal ini dikarenakan semakin suatu produk memiliki kriteria kualitas yang baik (warna kuning, aroma, kebersihan), memiliki daya tahan yang baik, tampilan menarik, dan terpercaya kualitasnya terkait rasa (indikator kualitas produk), maka konsumen tersebut akan merasa puas dengan produk yang telah dibelinya.

Sebagaimana hasil penelitian Aulia dan Hidayat (2017) menyatakan variabel kualitas produk berpengaruh signifikan terhadap kepuasan konsumen serta menambahkan bahwa standar bahan baku dan komposisi yang digunakan dapat memberikan rasa yang diinginkan konsumen, serta bukti nyata dari kualitas produk yang diberikan perusahaan akan semakin meningkatkan kepuasan konsumen. Hal ini sejalan dengan hasil penelitian dari Tristiana (2016) yang juga menyebutkan bahwa kualitas produk berpengaruh signifikan dan positif terhadap kepuasan konsumen, ia juga menambahkan bahwa semakin baik dan positif variabel bebas yang salah satunya kualitas produk akan meningkatkan kepuasan konsumen pemakai sepeda motor Honda Vario 125, pada Dealer Panji Perkasa Perdana.

Dari hasil yang menyatakan bahwa kualitas produk berpengaruh terhadap kepuasan konsumen, maka implikasinya adalah bahwa perlu diperhatikan dan diseleksi bahan baku telur yang diterima dari pemasok, karena bahan baku telur ini sangat menentukan kualitas produk telur asin, selain itu juga perlu memilih dan menetapkan standar dari batu bata yang digunakan untuk membungkus proses dari telur asin.

\section{Pengaruh Harga Terhadap Kepuasan}

\section{Konsumen}

Berdasarkan dari hasil uji $\mathrm{t}$ harga berpengaruh signifikan terhadap kepuasan konsumen memiliki nilai $\mathrm{t}$ hitung sebesar 
5,324 dengan tingkat signifikansi 0,000 yang kurang dari 0,05. Begitu juga menurut hasil penelitian Aulia dan Hidayat (2017) yang menyimpulkan variabel harga berpengaruh signifikan terhadap kepuasan konsumen. Oleh karena itu, strategi dan kebijakan harga yang diberikan dapat memperoleh pemasukan yang semakin meningkat, serta bukti nyata dari harga yang diberikan perusahaan akan semakin meningkatkan kepuasan konsumen.

Harga untuk produk KING Telur Asin tergolong tidak mahal di antara para kompetitor sehingga sesuai dengan manfaat produksi bagi para responden karena produk digunakan sebagai lauk pelengkap atau diolah lagi sebagai bahan baku masakan. Harga produk KING telur asin menurut jawaban responden menyebutkan harga produk mempengaruhi kemampuan pembeli bersifat homogen tetapi di sisi lain jawaban untuk pernyataan harga produk mempengaruhi keputusan pembelian lebih bersifat heterogen. Hal ini menunjukkan bahwa harga produk milik perusahaan tidak mahal sehingga memiliki kemampuan membeli akan tetapi untuk sampai ke tahap keputusan pembelian para responden memiliki jawaban yang bervariasi. Oleh karena itu hasil penelitian menyebutkan bahwa harga berpengaruh signifikan terhadap kepuasan konsumen. Jadi, semakin harga produk perusahaan sesuai dengan kualitas produk, dan bersaing dengan kompetitor, maka konsumen akan mendapatkan kepuasan atas pembelian pada produk KING telur asin.

Penelitian terkait harga dan kepuasan konsumen juga dapat dilihat dari Aulia dan Hidayat (2017) yang menyimpulkan variabel harga berpengaruh signifikan terhadap kepuasan konsumen. Oleh karena itu Aulia dan Hidayat menyebutkan bahwa strategi dan kebijakan harga yang diberikan dapat memperoleh pemasukan yang semakin meningkat, serta bukti nyata dari harga yang diberikan perusahaan akan semakin meningkatkan kepuasan konsumen. Demikian juga pada penelitian yang dilakukan oleh Tristiana (2016), hasil penelitian yang dilakukan menyimpulkan bahwa harga berpengaruh signifikan terhadap kepuasan konsumen. Pada kesimpulan penelitiannya menyebutkan bahwa harga merupakan jumlah uang yang harus dibayarkan konsumen untuk mendapatkan suatu produk guna memenuhi kebutuhan dan keinginan yang belum terpuaskan. Harga juga tidak hanya terkait 
tentang nominal tetapi bagaimana harga tersebut sesuai dengan keadaan produk yang dibeli seperti manfaat produksi yang dimiliki.

\section{KESIMPULAN DAN SARAN}

\section{kesimpulan}

Berdasarkan hasil pembahasan bab sebelumnya, dapat ditarik kesimpulan sebagai berikut:

1. Kualitas produk berpengaruh secara signifikan terhadap kepuasan konsumen KING Telur Asin, yang artinya kualitas produk merupakan faktor penting yang perlu mendapat perhatian karena akan terkait dengan kepuasan konsumen terhadap produk KING Telur Asin. Kualitas produk telur asin harus dijaga dari segi rasa dan tenggang waktu ketika produk tersebut disimpan.

2. Harga berpengaruh secara signifikan terhadap kepuasan konsumen KING Telur Asin, yang artinya harga merupakan faktor kedua yang penting selain kualitas produk yang berpengaruh terhadap kepuasan konsumen KING Telur Asin, untuk itu perlu diperhatikan bahwa harga merupakan jumlah uang yang harus dibayarkan konsumen untuk mendapatkan suatu produk guna memenuhi kebutuhan dan keinginan, sehingga perusahaan harus dapat menetapkan harga yang sesuai dengan kualitas produknya.

\section{Saran}

Untuk meningkatkan kualitas produk, KING Telur Asin dapat memberikan solusi dengan menetapkan standar kualitas untuk produknya. Standar kualitas dievaluasi sejak penerimaan bahan baku dari pemasok serta standar kualitas yang ditinjau dari kematangan dan kebersihan saat melakukan proses memasak. Selain itu juga terkait harga yang perlu dilakukan evaluasi rutin terhadap perubahan harga jual di pasar agar tetap dapat melakukan transaksi sesuai keadaan pasar yang sedang terjadi.

Untuk penelitian selanjutnya dengan topik yang sejenis disarankan dapat menambahkan variabel yang lainnya seperti promosi dan lokasi penjualan serta metode pengumpulan data yang digunakan dapat dilakukan melalui metode wawancara agar mendapatkan hasil yang lebih spesifik. 
Pengaruh Kualitas Produk dan Harga terhadap...(Ditia Fitriasshinta \& Tina Melinda)

\section{DAFTAR PUSTAKA}

Aulia \& Hidayat. (2017). Pengaruh Kualitas Produk, Kualitas Pelayanan dan Harga Terhadap Kepuasan Konsumen Amanda Brownies. JURNAL ILMU DAN RISET MANAJEMEN, Vol.6. No.5

Garvin, D. A. (2013). Managing Quality: The Strategic and Competitive Advantage. New York: Free Press.

Ghozali, I. (2016). Aplikasi Analisis Multivariete Dengan Program IBM SPSS 23. Semarang: Badan Penerbit Universitas Diponegoro.

Iglesias, M. P., \& Guillen, M. Y. (2016). Perceived Quality and Price: Their Impact on the Satisfaction of Restaurant Customers. International Journal of Contemporary Hospitality Management, Vol, 16, pp.373-379.

Kotler, P., \& Keller, K. L. (2014). Manajemen Pemasaran. Jakarta: Erlangga.

Lupiyoadi, R., \& Hamdani, A. (2014). Manajmen Pemasaran Jasa. Jakarta Selatan: Slemba Empat.

Marwanto, A. (2015). Marketing Sukses. Yogyakarta: Kobis.

Priyatno, D. (2014). SPSS 22: Pengolah Data Terpraktis. Yogyakarta: Penerbit Andi.

Ramli, S. (2013). Bacaan Wajib Para Praktisi Pengadaan Barang/Jasa Pemerintah. Jakarta Selatan: Visi Media.

Rangkuti, F. (2013). Customer Service Satisfaction \& Call Center Berdasarkan ISO 9001. Jakarta: Gramedia Pustaka Utama.

Sugiyono. (2016). Metode Penelitian: Kuantitatif, Kualitatif, dan R\&D. Bandung: Alfabeta.

Sujarweni, V. W. (2015). SPSS Untuk Penelitian. Yogyakarta: Pustaka Baru.

Sunyoto, Danang. (2013). Manajemen Pemasaran. Jogjakarta, Caps.

(2013), Metode dan Instrumen Penelitian Ekonomi dan Bisnis, Jogjakarta, Caps

Tandon, U., Kiran, R., \& Sah, A. (2017). Analyzing Customer Satisfaction: Users Perspective towards Online Shopping. Nankai Business Review International, Vol. 8, pp. 266-288.

Tjiptono , F., \& Chandra, G. (2013). Pemasaran Strategik. Yogyakarta: Penerbit ANDI.

Tjiptono, F. (2014). Manajemen dan Strategi Merek. Yogyakarta: Andi.

Wijaya, C. V. (2017). Pengaruh Harga, Kualitas Pelayanan dan Kualitas Produk Terhadap Kepuasan Konsumen Depot Madiun Masakan Khas Bu Rudy. AGORA, Vol.5 No.1.

Rezki, R. (2014). Pengaruh Kualitas Produk, Harga, Lokasi dan Promosi terhadap Keputusan Pembelian Ruko pada CV. Sinar Jaya Global Steel Padang. Jurnal Manajemen dan Kewirausahaan , 1-21. 
Gulla, R., Oroh, S. G., \& Roring, F. (2015). Analisis Harga, Promosi, dan Kualitas Pelayanan terhadap Kepuasan Konsumen pada Hotel Manado Grace Inn. Jurnal EMBA, Vol 3 No1, pp.1313-1322.

Setyo, P. E. (2017). Pengaruh Kualitas Produk dan Harga terhadap Kepuasan Konsumen "Best Autoworks". Jurnal PERFORMA, Vol. 1 No.6, pp.755-764. 